\section{PP-193 腎細胞癌の臨床的検討}

\section{埼玉医科大学総合医療センター泌尿器科}

吉永 敦史, 高木 大輔,山下 高久, 石井 信行,

松田 隆晴, 寺尾 俊哉, 永松 秀樹, 諸角 誠人,

山田 拓已

(緒言) 近年、分子標的薬剤の登場により、腎細胞癌の治療は大 きく変貌を遂げているが、いまだ手術療法が主体である。今回わ れわれは当科における腎細胞癌について臨床的検討を行った。

(対象と方法) 1986 年から 2008 年までの 22 年間に当科にて腎 細胞癌と診断し治療した 295 例を対象とし、腎癌取り扱い規約 第 3 版に準じ臨床的検討を行った。生存率は Kaplan-Meier 法 により算出し、有意差検定は Log rank test を用いた。(結果) 208 例、女性 87 例。年齢は 23-86 歳 (中央值 59 歳)。患側は右 147 例、左 148 例。術後観察期間は 1-257 ケ月(中央值 40 ヶ月)。手 術方法は根治的腎摘除術 276 例、腎部分切除術 14 例、生検 5 例。組織学的分類は淡明細胞癌 276 例、非淡明細胞癌 19 例。疾 患特異的 5 年生存率（5生率）は $81 \%$ であり、深達度別 5 生率 は pTla 98\%、pT1b $89 \% 、$ pT2 79\%、pT3a 66\%、pT3b 64\%、 pT3c $0 \% 、$ pT4 33\% であった。異型度別 5 生率は G1、G2、G3 でそれぞれ85、84、58\%であり、增殖浸潤様式別 5 生率は

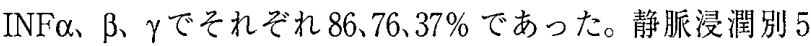
生率はv（-）92\%、v（+）53\%（p<0.001）であった。(結語) 従来の報告同様、 high stage あるいは high gradeのものが予後 不良であり、その他の因子に関しても検討する予定である。

\section{PP-194術後 10 年以降に発症した腎癌転移症例 の臨床的検討}

\section{金沢医療センター泌尿器科}

越田 潔, 石浦 嘉之,飯島 将司

過去 22 年間に経験した腎細胞癌において、術後 10 年以降 に再発を認めた症例は 5 例であった。転移初発部位は、肺； 3 例、骨； 1 例、胆囊； 1 例で 3 例において、脳と骨、脳、 対側腎にそれぞれ転移が続発した。肺転移は摘出術施行後、 小結節の再発みるも無治療にて増大傾向は認められなかっ た 1 例。IFNにより 5 年間 NCが 1 例、胸膜浸潤、無気肺、 対側多発転移と進行した 1 例であった。脳転移は 2 例とも ガンマナイフにより NC、胆震転移は摘出術後、NED で 6 年経過した。骨転移はTAE，放射線治療が施行され、1 例は PD で骨転移発症後 1 年で癌死、他の 1 例は PD なが ら TAE を反復し 2 年経過している。再発時の子後因子(転 移発症までの期間・PS・転移臓器数・筫血・炎症反応）の 検討結果は良好で、過去の報告によれば 3.5 年の平均余命 が期待される。これまでのところ 4 年で死亡した 1 例を除 き、平均 4 年の経過で生存している。「結語」術後 10 年以上 経過した転移症例は全般としては転移発症後の予後は良好 である。再発は 1 ケ所から始まるので、摘出術も選択肢に あがる。脳転移のコントロールは比較的良好であったが、 骨転移は增殖が速く予後を規定する可能性が高い。肺転移 においてはある時点から急激に增悪することがあり注意を 要する。
PP-195

自己活性化 $\gamma \delta$ 型 $T$ 細胞を用いた養子免 疫療法で長期生存の得られた進行性腎癌 の 2 症例

東京女子医科大学医学部泌尿器科学", 東京女子医科大学 東医療センター2

小林 博人 ${ }^{1}$, 近藤 恒德 ${ }^{1}$, 橋本 恭伸 ${ }^{1)}$, 伊藤 文夫 ${ }^{21}$, 合谷 信行 ${ }^{11}$, 中澤 速和 ${ }^{2}$, 田邊 一成1)

新規分子標的薬の登場により進行性腎癌の治療が大きく変化して いるが、長期投与による成績や副作用など、検討を要する課題は多 い。私たちは自己活性化 $\gamma \delta$ 型 T 細胞を用いた盖子免疫療法も行っ ている。 $\gamma \delta$ 型 $\mathrm{T}$ 細胞は、末梢血 $\mathrm{T}$ 細胞の数\%を占め、主として感 染防御に㗢いているが、抗腫慯活性も認める。本治療を開始後、2 年以上の生存が得られた 2 人について報告する。症例 $1: 69$ 歳、男 性。2004 年 6 月、根治的右腎摘除術挹よび IVC 内腫痬塞栓除去を 施行、淡明細胞癌、G3、pT3bNOMO であった。術後 IFN- $\alpha$ をする

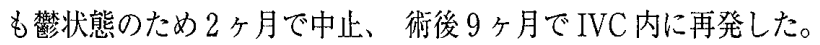
2005 年 4 月より本潦法を 1 2 ケ月に一回、外来で計 24 回施行し た。末梢血 $\gamma \delta$ 型 T 細胞が $30 \%$ 以上と高い割合を保ち、多臟器への 転移は認めなかったが、局所再発巣が徐々に増大し、08 年 4 月亡く なった。症例 $2: 65$ 歳、男性。病的骨折でRCC が見つかり、2003 年 7 月に根治的右腎的除術を施行、淡明細胞癌、G2、pT1bN0M1 (骨と肺)であった。術後 IFN- $\alpha$ を施行し、腫瘍縮小を認めるが PD となった。2006 年 10 月より本療法を 1 ケ月に一回、外来で計 19 回施行した。本症例も末梢血 $\gamma \delta$ 型 T細胞が $30 \%$ 以上と高い割合 を保ち、腄場は增大傾向ではあるが SD で経過している。

\section{PP-196 Xp11.2 転座/TFE3 融合遺伝子関連腎癌 の 1 例}

宮崎大学医学部泌尿器科学 ${ }^{11}$, 宮崎大学医学部腫瘍 - 再生 病態学 ${ }^{2)}$, 宮崎大学医学部小児科学 ${ }^{3)}$, 宮崎県立宮崎病院 泌尿器科 ${ }^{4}$

向井 尚一郎 ${ }^{1}$, 上村 敏雄 ${ }^{1)}$, 田中 弘之 ${ }^{2)}$, 盛武 浩 ${ }^{3)}$, 長野 正史 ${ }^{4}$, 蓮井 良浩

$\mathrm{Xp11.2}$ 転座/TFE3 融合遺伝子関連腎癌 (以下、Xp11.2 転 座型腎癌) はその多くが小児、若年者にみられる稀な腫瘍であ る。今回我々は、15 歳の女性に発症したXp11.2 転座型腎癌 の一例を経験したので報告する。病歴、経過】2008 年 1 月肉眼 的血尿を主訴に近医を受診し、精査にて右腎腫瘍と診断され、 当科紹介となった。腹部造影 CT では、右腎に辺縁が不正に造 影され、内部に液体販留を伴う径約 $7 \mathrm{~cm}$ の腫瘍を認めた。同年 2 月経腹胿的アプローチにて根治的右腎摘除術を施行した。術 中に腫大を認めた腎門部リンパ節 2 個も摘除した。術後経過 は良好であった。診断】肉眼的に腫瘍は内部に広範な出血壊 死を伴っており、辺縁に充実性の腫瘍組織を認めた。病理組織 学的に腫瘍は、胞体の大きい淡明な腫瘍細胞で構成されてお り、腫痬組織内に砂粒状石灰化が散見された。摘出したりンパ 節は転移であった。腫瘍の凍結組織の遺伝子学的解析では、 $\mathrm{t}$ $(\mathrm{X} ; 22)(\mathrm{p} 11.2 ; \mathrm{q} 11.2)$ の転座が認められた。上記所見はこれま でに報告されているXp11.2 転座型腎癌例に合致している が、転座パターンとしては新規であり、現在も免疫組織、遺伝 子学的精查が進行中である。これらのデー夕も含め報告する。 